EGU21-43

https://doi.org/10.5194/egusphere-egu21-43

EGU General Assembly 2021

(c) Author(s) 2021. This work is distributed under

the Creative Commons Attribution 4.0 License.

\title{
Antimony leaching from mine waste and soil at a stibnite mine in North-Vietnam
}

\author{
Valérie Cappuyns ${ }^{1,2,3}$, Axelle Van Campen $^{3}$, and Jillian Helser ${ }^{1,2,3}$ \\ ${ }^{1}$ Centre for Economics and Corporate Sustainability, KU Leuven, 1000 Brussels, Belgium (valerie.cappuyns@kuleuven.be) \\ ${ }^{2}$ Institute for Sustainable Metals and Minerals, KU Leuven, 3001 Leuven, Belgium \\ ${ }^{3}$ Department of Earth and Environmental Sciences, KU Leuven, 3001 Leuven, Belgium
}

While the impact of Sb mining is documented in literature from China, Australia, and Europe, little information is available concerning the environmental impact of Sb mining in Vietnam. This paper presents the results of an exploratory study of mine waste and soil samples from the Mau Due mine (North Vietnam). Besides the chemical and mineralogical composition of soils, waste rock and slag samples, water-soluble and exchangeable/reversibly adsorbed Sb species were also determined, as well as the $\mathrm{pH}$ dependent release of Sb. Stibnite and pyrite were found in slag and waste rock samples, with total Sb concentrations in the range of 191-15,699 mg/kg. Soils were characterized by $\mathrm{Sb}$ concentrations in the range of $47-95 \mathrm{mg} / \mathrm{kg}$.

The leaching test show that, when mine waste stored on the Mau Due mining site comes into contact with water, up to $1.7 \%$ of its total Sb content is leached. However, because of the high Sb content of some of the waste materials, high dissolved Sb concentrations are found in the leachates. Some of the investigated samples are listed by the EU as absolutely hazardous waste, because of the leaching potential of Sb. Especially in the rainy season, leaching of $\mathrm{Sb}$ from the mine waste and slags can contribute to the dispersion of Sb. An increased release of Sb was observed from $\mathrm{pH} 7.5$ to 12.8 . Modelling also indicated that the dissolution of stibnite and reprecipitation as $\mathrm{Sb}(\mathrm{OH})_{3}$ is not the only factor that explains Sb solubility. Desorption reactions and the incorporation of $\mathrm{Sb}$ in other mineral phases are most likely also important factors determining the retention and release of $\mathrm{Sb}$ from the waste materials and slags.

The waste heaps consist of fine-grained material, that can be prone to wind erosion in the dry season. Therefore, measures to prevent the further dispersion of $\mathrm{Sb}$ and other potentially hazardous elements, both via leaching and wind erosion, should be put in place. In order to establish regulations for environmental protection, it is necessary to raise governmental and public awareness. The high concentrations of Sb imply an important potential hazard for soils, water bodies, and the food chain, for which appropriate measures are necessary.

\section{Reference}

Cappuyns, V., Van Campen, A., Helser, J. (2020). Antimony leaching from soils and mine waste from the Mau Due antimony mine, North-Vietnam. Journal Of Geochemical Exploration, 220, 
Art.No. 106663, 1-13. doi: 10.1016/j.gexplo.2020.106663 